\title{
Critical Analysis of the Challenges of Solid Waste Management Initiatives in Keko Machungwa Informal Settlement, Dar es Salaam
}

\author{
Samson Elisha Kasala \\ Department of Urban and Regional Planning, Ardhi University, Dar es Salaam, Tanzania \\ Email: samson.kasala@gmail.com
}

Received 1 July 2014; revised 5 August 2014; accepted 29 August 2014

Copyright (C) 2014 by author and Scientific Research Publishing Inc. This work is licensed under the Creative Commons Attribution International License (CC BY). http://creativecommons.org/licenses/by/4.0/

(c) (i) Open Access

\section{Abstract}

Solid waste is inevitable because by nature every human activity generates a certain amount of solid waste. The rate of solid waste generated tends to increase with the increase in population. Despite existence of various efforts on solid waste collection, still the quantity of solid waste collected is small compared to the solid waste generated. The situation is even worse in unplanned settlements of developing countries, where, ineffective solid waste collection is contributed to by haphazard solid waste disposal and hence environmental pollution. Therefore, having an effective and efficient solid waste management system is a major challenge in cities of developing countries, and thus more consulted efforts are needed. This paper presents finding based on the study carried out in Keko Machungwa informal settlement in Dar es Salaam, Tanzania. The study explored challenges facing solid waste management initiatives in Keko Machungwa and recommended measures for improvement. Data for this study was collected through documentary review, household interviews, focus group discussions, physical observations and official interviews. The analysis reveals that solid waste generated in Keko Machungwa is 16 tones per day, among those, only 4.56 (less than 50\%) are collected. About 11.44 tones of uncollected waste are illegally dumped into a seasonal stream and in different vacant lots hence causing blockage of the seasonal stream. Different groups engaged in solid waste collection are deterred by many challenges. The challenges include: lack of cooperation among the existing solid waste collection organs, inaccessibility in some places, low public participation, financial constraints and unwillingness of local community to pay for solid waste collection fees. The paper recommends four options on how solid waste management, particularly collection in Keko Machungwa can be enhanced. 1) Alliance among the existing organ, 2) placing dust-bins in different points within the settlement, 3) linking the fees of solid waste collection to other public services and 4) education and awareness creation campaigns accompanied by community stakeholder consultations. 


\section{Keywords}

\section{Solid Waste Collection, Solid Waste Management, Collection Fees}

\section{Introduction}

There have been numerous debates about population growth in many cities of developing countries. A large number of researchers [1]-[3] agree that the major factors that lead to an increased number of people in cities are seeking a better life, among others. Against their hopes, many people who moved to urban areas have found themselves living in difficult life situations in poorly serviced informal settlements [2]. The result is increasing in population that causes changes in lifestyle, pressure on social services, environment and land use [2]. Significant increase in the number of people in cities is one of the major reasons as to why many municipalities find themselves incapable of providing essential services especially solid waste collection.

The case in point is reaffirmed by Minghua et al., 2009 [4]. Minghua et al., 2009 [4] argue that in developing countries increasing number of urban dwellers, uncontrolled urbanization and the rise in community living standards have significantly contributed to the large-scale production of solid waste. The situation is worse in African cities where, the ability of municipalities to deliver solid waste management services is limited compared to the level of generated solid wastes [5]-[7]. Solid waste management is therefore among the major challenges facing cities in many developing countries, particularly Africa.

Factors that prohibit effective solid waste management by municipal authorities in developing countries have been explained by a number of researchers. Among others they include: Financial constraints [8]-[10], technical factors [11] [12], inadequate service coverage and operational inefficiencies of services [9] [11]. Others include unwillingness of the users to pay for the solid waste collection services [6] [13] and poor infrastructures [11] [14]. These reportages indicate that, due to these constraints most of the wastes generated within municipalities are inadequately collected and managed thereby causing serious threat to the environment.

\section{Waste Management in Dar es Salaam City}

For a long time Waste management in urban centres of African countries has been centralized [11] [15] [16]. The situation applies in Dar es Salaam City where Local Authorities only were responsible for solid waste management. The Tanzanian Local Government Act of 1982 (Section 55 grams) provides Urban authorities with the mandate "to remove refuse and filth from any public or private place" and to provide and maintain public refuse containers for the temporary deposit and collection of waste [11].

Like in the rest of African cities, the monopoly power of local authorities (the public sector) in providing solid waste management services has been constrained by many factors. They include inter alia, inadequate technical capacity, cumbersome procurement procedures [16] and inadequate financial resources [10]. These constraints in Dar es Salaam city have led to substantial negative environmental impacts. This situation is what led to public-private sector involvement in solid waste management. Under this arrangement, a number of ways have been used to collect solid waste. They include: use of private companies, community based organizations, associations and individuals who collect waste at a fee. However, with these options, solid waste management remains a questionable endeavor in different areas of Dar es Salaam City. The argument that Solid waste management in Dar es Salaam city is questionable is justified by the fact that, currently as presented in Table 1 the amount of solid waste collected (1533 tons/day) is lower that the generated amount (4161 tons/day) [17].

The generated solid waste of 4161 tons/day presented in Table 1 represents a generation rate of 0.95 $\mathrm{kg} / \mathrm{cap} / \mathrm{day}$ based on a population of 4,364,541 [18]. Further, the current solid waste generation rate of 0.95 $\mathrm{kg} / \mathrm{cap} /$ day in Dar es Salaam City has increased by $0.55 \mathrm{~kg} / \mathrm{cap} / \mathrm{day}$ from $0.4 \mathrm{~kg} / \mathrm{cap} / \mathrm{day}$ in 2003 [19]. This indicates that solid waste generated is increasing with the increase of population, among others. Moreover, the solid waste generation rate of Dar es Salaam City is higher than typical values for developing countries which range from 0.4 to $0.6 \mathrm{~kg} / \mathrm{cap} /$ day [17].

Given the fact that the amount of solid waste that is properly collected in Dar es Salaam City is less (about $37 \%)$ than the amount generated, solid waste management is becoming more problematic. This is despite the 
Table 1. Solid waste generation and collection (tons/day) in the city of Dar es Salaam.

\begin{tabular}{cccc}
\hline Municipality & Generated amount (tons/day) & Collected amount (tones/day) & \% collected \\
\hline Ilala & 1100 & 430 & 39 \\
Temeke & 1035 & 280 & 27 \\
Kinondoni & 2026 & 823 & 31 \\
Total & 4161 & 1533 & 37 \\
\hline
\end{tabular}

Source: Bubegwa 2012 citing DDC 2010 [17].

fact that SWM was among the nine issues identified and prioritized to be addressed at city level during the first Dar es Salaam City consultative workshop on environment [20] [21]. This background necessitated conducting the current study, whose main objective was to explore the challenges facing Solid Waste Management initiatives in Keko Machungwa Informal settlement and to recommend sustainable measures. The study specifically aims to 1) explore existing organs dealing with solid waste collection and how those organ operates, 2) analyze solid waste disposal systems in Keko Machungwa, 3) explore the challenges facing solid waste management (SWM) in Keko Machungwa, and 4) Recommend measures for improving solid waste management.

\section{Description of the Case Study Area}

Geographically, Keko Machungwa informal settlement (Figure 1) is within Temeke Municipality in Dar es Salaam City. The settlement stretches along Kilwa Road, which is a trunk road that leads to Lindi and Mtwara in the Southern part of Tanzania. The settlement is about 3 kilometers from the Dar es Salaam City Centre. Being close to the Central Business District (CBD), makes the area attractive for different activities including: trading, settlement development, and investments. According to the 2012 Population Census, Keko Machungwa had a population of 16,648. Just as other informal settlements in Dar es Salaam City, Keko Machungwa lacks proper ways of solid waste management and the existing ones are ineffective. As a result majority of its population dump solid waste illegally and haphazardly in the existing rivers and in any vacant space. The problem is acute with an increasing number of population; therefore if care is not taken the result will be significant negative environmental impacts. In this regard, this paper attempted to examine challenges facing solid waste management in Keko Machungwa with a view to contribute to improving solid waste management initiatives within the settlement.

\section{Methodology}

The study was conducted using primary and secondary information. Primary information was collected through household interviews, focus group discussions, physical observations and official interviews. In selecting households for interview, procedures followed where 1) determine the sample size (70 households) for interview using the mathematical formula obtained in Baradyana and Ame (2005) [22], 2) obtain a list of head of households for Keko Machungwa from voters' list of 2012, and 3) Selecting the 70 households randomly using the random table. Structured questionnaire was used to collect information from the selected households. Focus group discussions were held with groups involved in solid waste collection. Official interviews were held with sub ward leaders and chairmen of the community groups who are involved in solid waste collection. Secondary information for the purpose of knowing what others have done in the subject of solid waste management was collected through documentary review.

\section{Results and Discussion}

\subsection{Solid Waste Collection: Organs Involved and How They Operate}

Blockage of drainage channels due to haphazard dumping of solid waste (see Figure 2) is a major problem reported to contribute to the problem of flooding in Keko Machungwa [23]. This situation led the local government to convince the local community to cooperate in solid waste management initiatives. Local Government efforts helped the establishment of the community association namely "Keko Machungwa Usafi" and Keko environmental. The sub ward chairman reported that the two groups were established in 2005 and they were re- 


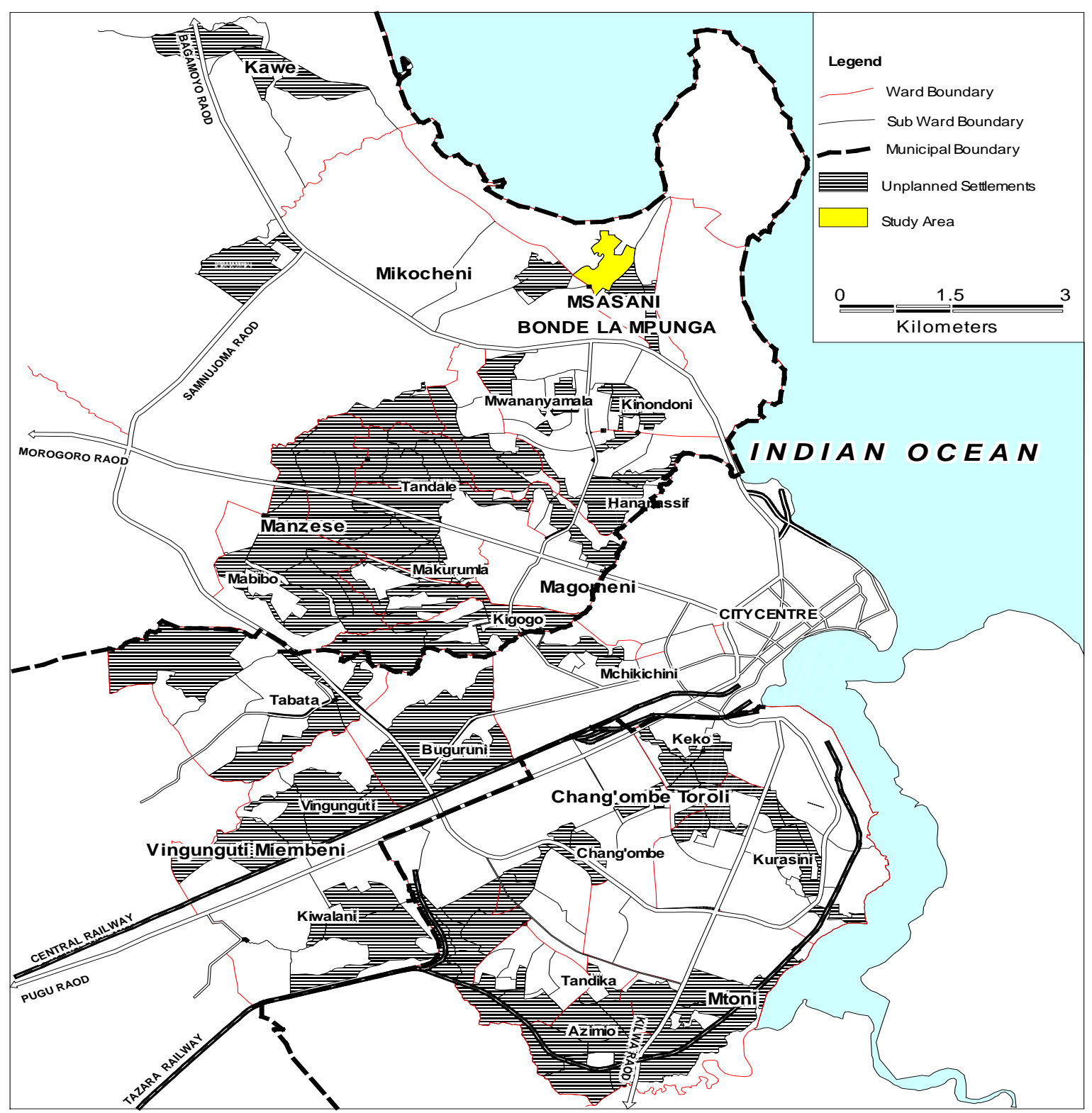

Figure 1. Location of Keko Machungwa in the context of Dar es Salaam City.

sponsible for collecting solid waste and transport it into the municipal collection places. Every house (regardless of the number of tenants) were required to pay Tshs 1000 (0.6 USD) ${ }^{1}$ as waste collection fee. Solid waste management by Keko Machungwa Usafi and Keko environmental was not sustainable due to financial constraints and inadequate cooperation from the local community. Some local community members were not ready to pay the agreed as waste collection fee, and thus the groups were not able to recover the money spent to coversolid waste management costs.

Condition of clogging of river and individual drainage facilities with solid wastes that reduce the carrying capacity of the drainage systems continued. To minimize this problem, the local government increased efforts to educate the local community. These efforts contributed to the establishment of other two community organization namely: Tanzania Federation for the Urban Poor (Tumaini letu Group) and Keko Machungwa Mazingira Usafi (KEMAMUSA).

KEMAMUSA is a community organization established in 2008 to replace previous organizations (Keko

\footnotetext{
${ }^{1} 1$ Tshs is equivalent to 0.0006 USD as at June, 2014, available at http://www.currency.me.uk/convert/tzs/usd.
} 

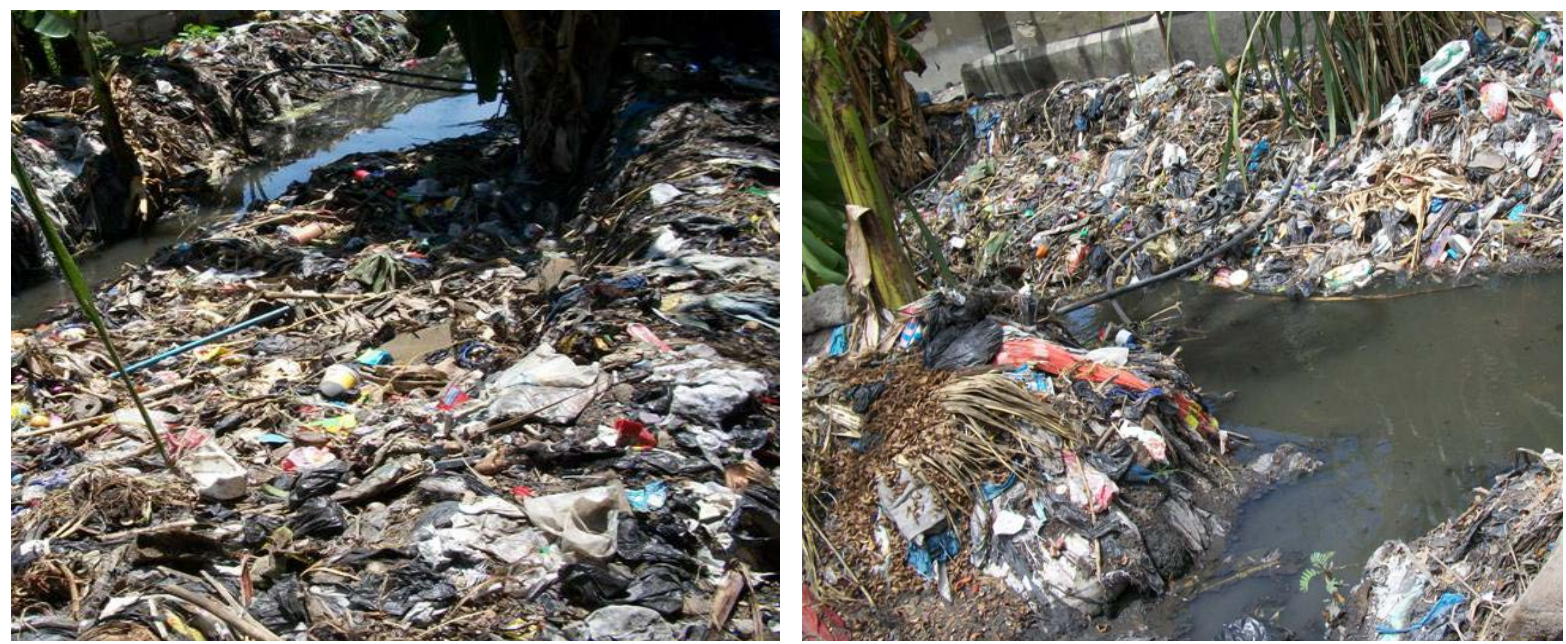

Figure 2. Illegal dumping of solid wastes in the vicinity of a seasonal stream.

Machungwa Usafi and Keko environmental), which were ineffective in managing solid waste. KEMAMUSA was given authority to manage solid wastes by ward development committee. It was reported by the chairman of KEMAMUSA that, they were dealing with solid waste management under the supervision of the contractor who, at the time of this study, was entrusted to collect solid waste in their settlement.

In the discussion with solid waste collectors it was revealed that, at the beginning each house was required to transfer solid waste up to a collection points. The solid waste collection fee charged was Tshs 3000 (1.8 USD), this charge was regardless of the number of tenants in a house. Very few people (22\%) responded to this style, majority (78\%) were not bringing the solid wastes for a reason of inconvenience, time consuming and absence of participation in decision making.

A solution to that problem was to reduce solid waste collection fee from Tshs 3000 to Tshs 1000 per month for every house. Still, response was very low; people were reluctant to pay Tshs 1000 per house. To improve collection of solid waste fee a new style i.e. door to door system of collecting solid waste was introduced. In this option each household is required to pay between Tshs 300 (0.18 USD) and Tshs 1000 per collection depending on the quantity of waste. Solid waste collectors pass in streets to collect solid waste twice a week. Solid waste collectors' complained about working equipment, inaccessibility to some areas, and unwillingness of the local community to pay the agreed waste collection fee.

Moreover, in the discussion with the chairman of KEMAMUSA, it was reported that "at the time when this study was being conductedthe group collected solid wastes from about 1000 households”. Given the Tanzanian average household size of 4.8 [18], it means that KEMAMUSA collects solid wastes from about 4800 people per day. Therefore, based on the waste generation rate of $0.95 \mathrm{~kg} / \mathrm{cap} / \mathrm{day}$, the amount of solid waste collected in Keko Machungwa is $4560 \mathrm{~kg}$ (equivalent to 4.56 tones) per day. The quantity of solid waste collected (4.56 tones per day) is smaller than the generated amount of 16 tones per day (Table 2). According to URT (2013) [18], Keko Machungwa has a population of 16648, this indicates that the settlement generates solid waste of about $15815.6 \mathrm{~kg} /$ day (equivalent to 16 tones per day). These results indicate that about 11.44 tones of waste from 11,848 people are not collected. Table 2 presents a comparison of solid waste generated and collected in Dar es Salaam City and Keko Machungwa.

It is apparent in Table 2 that, more than 50 percent of the solid waste generated in Dar es Salaam (67\%) and Keko Machungwa (71.5\%) is not collected. This indicates that different areas in Keko Machungwa and in Dar es Salaam City in general will continue to be dirty. This situation will contribute to environmental pollution and various disease outbreaks.

In addition, within the settlement there is a group known as Tumaini Letu Group (Federation for the Urban Poor), which was established in 2008. Tumaini letu group is working under the supervision of an NGO called Centre for Community Initiative (CCI). CCI through Tumaini Letu group implemented sanitation related initiatives. According to the group chairperson the initiatives include: 1) Solid waste collection through "Participatory Hygiene and Sanitation Transformation (PHAST) program”, this is a participatory approach involving all resi- 
Table 2. Solid waste generation and collection in Dar es Salaam and in Keko Machungwa.

\begin{tabular}{ccccc}
\hline & Total population & $\begin{array}{c}\text { Waste generated } \\
\text { (tones per day) }\end{array}$ & $\begin{array}{c}\text { Waste collected } \\
\text { (tones per day) }\end{array}$ & $\begin{array}{c}\text { Percentage of uncollected } \\
\text { waste }\end{array}$ \\
\hline Dar es Salaam City & $4,364,541$ & 4161 & 1533 & 67 \\
Keko Machungwa & 16,648 & 16 & 4.56 & 71.5 \\
\hline
\end{tabular}

Source: Bubegwa 2012 [17] and Field survey 2013.

dents, 2) Awareness creation campaigns about the risks of using river streams as solid waste disposal sites, this targeted residents who live close to river streams, 3) Mobilizing funds for cleaning river streams, and 4) facilitate construction of toilets. Survey results revealed that the engagement of Tumaini Letu Group in mobilizing solid waste collection, at the time the same activity was outsourced to a contractor, caused conflicts. Thus at the moment Tumaini Letu group has refused to engage itself in solid waste collection.

Despite the existence of various organs dealing with solid waste management, the physical inventory done in various areas within Keko Machungwa revealed that, the condition of many areas in the settlement is not satisfactory and does not meet the environmental and health standards (Figure 2). Some of the causes of the condition as revealed by this study include: arbitrary disposal of waste causes backlog of waste especially on the stream; absence of dustbins causes local community to throw solid waste haphazardly; lack of cooperation between existing organs dealing with solid waste collection; informal housing development which limit door to door solid waste collection and unwillingness of the local community to pay for the set solid waste collection fees.

In a discussion about the reluctance of somelocal community members to pay for the solid waste collection fee, executive chairman of the settlement reported that

"It is a disappointing practice because the solid waste collection fee charged is small compared to prevailing market rates”.

We have worked hard to educate the local community but still response is not satisfactory. The chairman reported further during a public awareness creation campaign that the costs of paying for the solid waste management (SWM) fee is very low compared to costs on other services like electricity, water and mobile phones. For electricity for example, each household (depending on their uses and agreement) contributes between Tshs 5000 (3 USD) to Tshs 15,000 (9 USD) per month. Also, at least every household owns a mobile phone, running a mobile phone is very expensive, it costs at least 1000 Tanzanian shillings per day. It is surprising to see that a resident who can pay such costs forelectricity and mobile phone is not able to pay a small amount of money for solid waste collection. This finding indicates that, there is a need to link solid waste collection fee toother public services provided.

\subsection{Solid Waste Disposal}

Analysis of household survey revealed that solid waste disposal methods that are used by local people in Keko Machungwa settlement include: dumping solid waste into open spaces and into the vicinity of rivers (62\%) (Figure 3), burning solid waste in house backyards (13\%), communal collection (11\%), door to door collection (8\%) and burying solid wastes into the ground (6\%) (Figure 4). It is apparent in Figure 4 that, a small number of people (19\%) use a safe method of waste disposal. Therefore, it can be concluded that Keko Machungwa lacks proper solid waste management, consequently large number of residents (62\%) dispose solid waste into open drains and natural streams. This practice indicates that, the environment in Keko Machungwa is at risk in terms of polluted air, water pollution and related health risks.

During focus group discussions with solid waste collectors, it was confirmed that a large quantity of solid wastes is not collected. This is contributed by many reasons: the tendency of the local community to use seasonal rivers as solid waste disposal site; use of handcarts (Figure 5) that are not reaching every part of the settlement due to narrow paths. Unwillingness of the local community to bring the solid wastes in collection places. This further contributes to the increase of heaps of solid wastes and hence causes flooding when it rains heavily due to blockage of runoff.

Despite the fact that the local government have tried to devise different ways of solid waste collection, established organs to collect solid wastes have been failing. Failure of collecting solid wastes may have contributed to the problem of throwing solid wastes into available seasonal streams and other vacant lots. Also, the study has revealed that Keko Machungwa settlement lacks designated places for solid waste disposal and collection. This 


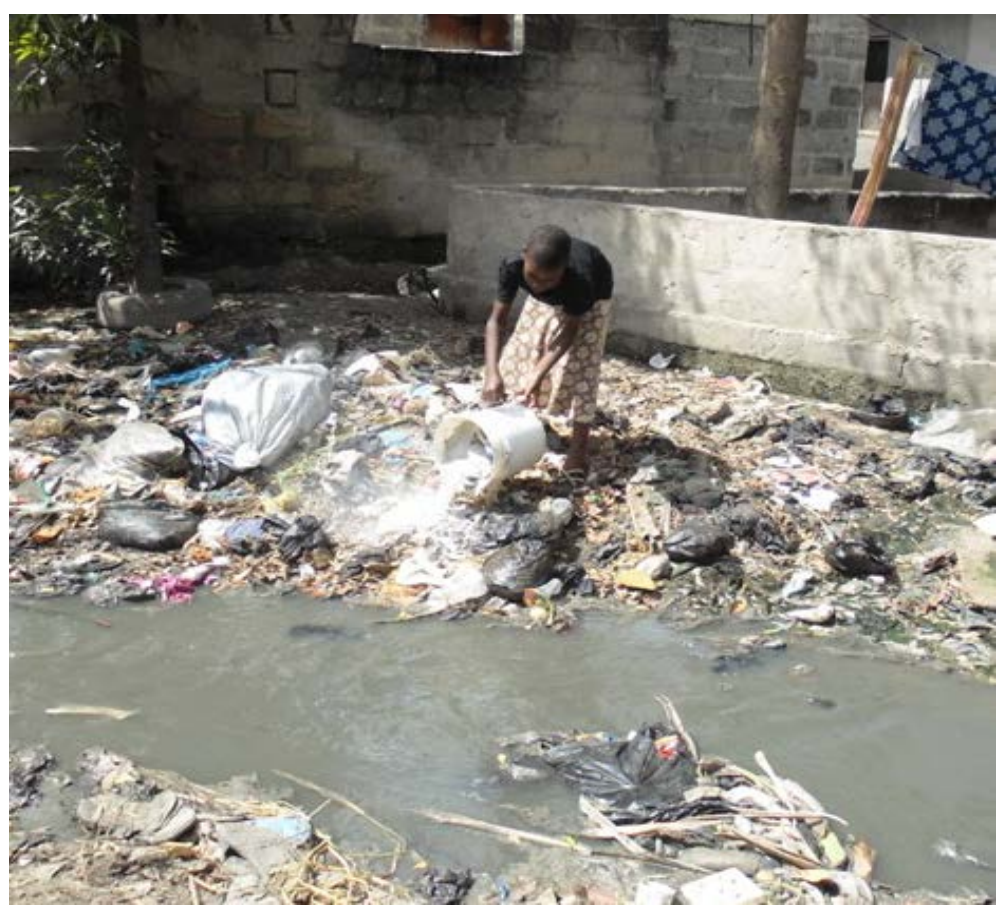

Figure 3. A Keko Machungwa resident disposing solid waste to the river.

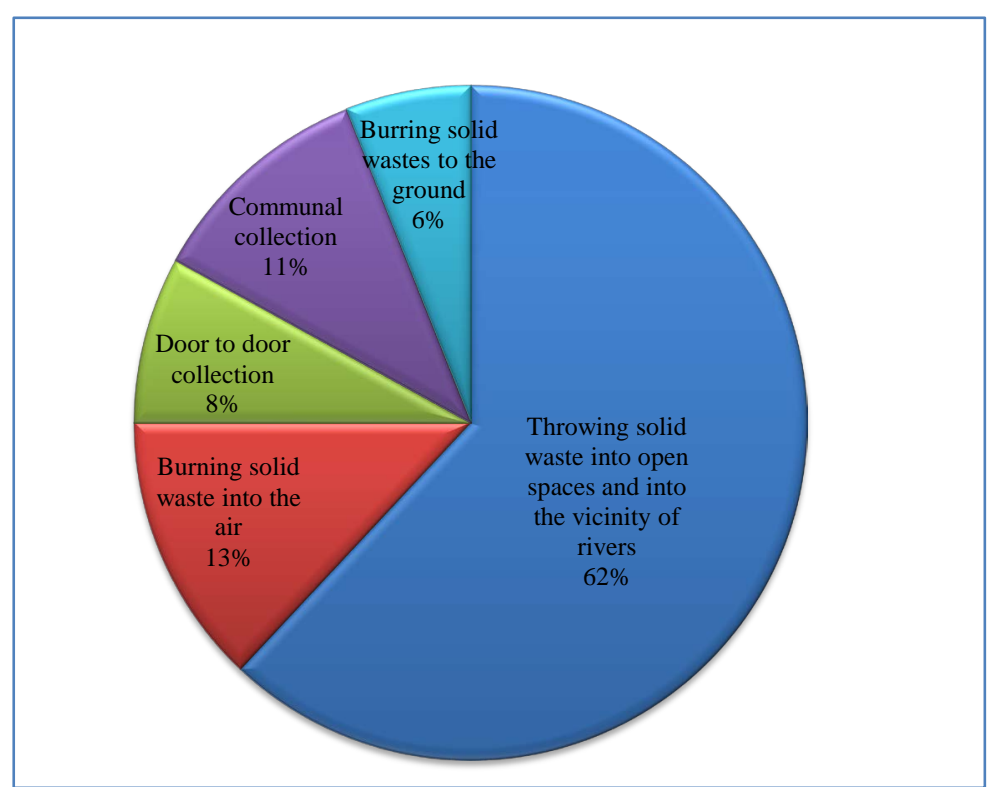

Figure 4. Solid waste disposal options in Keko Machungwa.

means that people who live in areas that are inaccessible (like the case is for the residents living in the valley of Keko Machungwa) they do not have alternative disposal options. They are therefore forced to use river streams and any open spaces or vacant lots within their reach. Inappropriate solid waste collection system can be a source of pollution and post-flood risks.

\subsection{Challenges of Solid Waste Collection and Management}

5.3.1. Social Challenges: INADEQUATE Community Participation

While the local community is aware of the negative impacts of poor solid waste management, there is lack of 


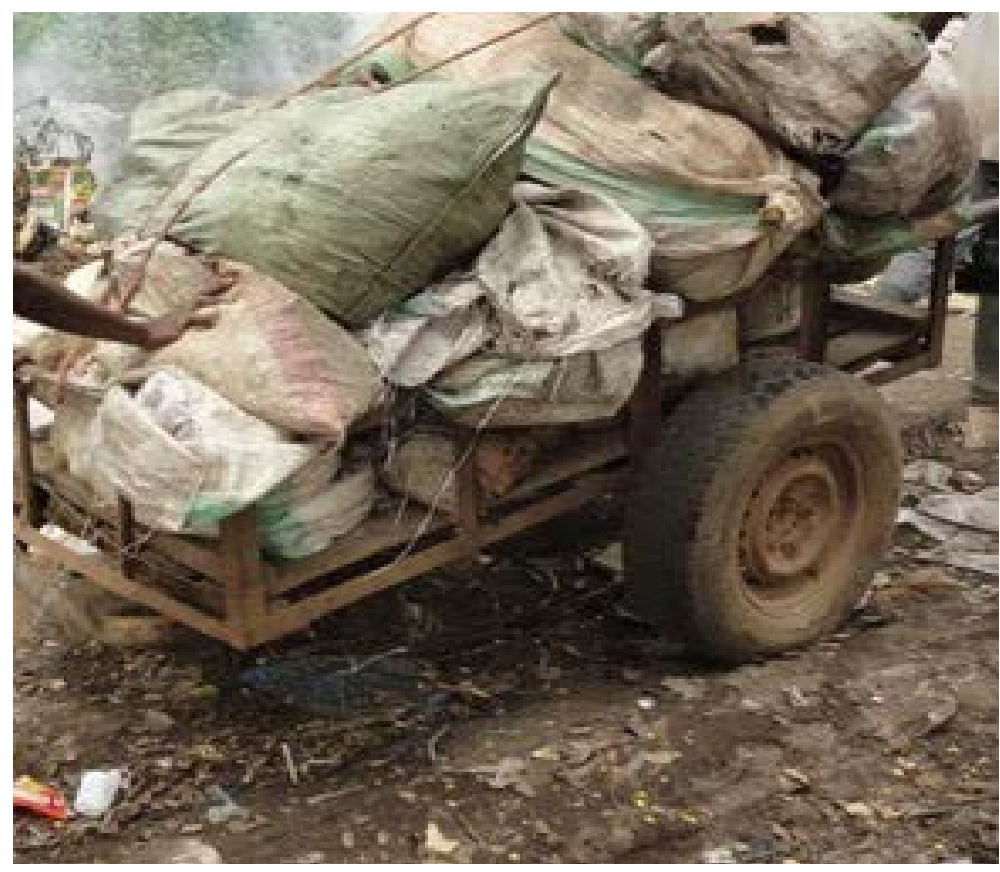

Figure 5. A handcarts used for collecting solid wastes.

public participation and cooperation in solid waste management. The study revealed that, a number of community organization were established for solid waste collection, however, they were found to fail due to lack of sufficient cooperation from the local community, among others. Between 4208 households, about 1000 (23.8\%) households participate in solid waste management through paying for solid waste collection fees. This indicates that a large number of households (3208) are not participating in solid waste management. This analysis implies that proper ways of solid waste management are given a very low priority by the local community in Keko Machungwa, this practice would lead to substantial negative environmental impacts.

\subsubsection{Spatial Challenges: Inaccessibility}

There is a challenge of accessibility in some parts of the settlement (mostly areas along the valley). This situation has been contributed to by the informal housing development, whereby, houses have been constructed close to each other without setbacks. This has constrained accessibility (see Figure 6). The study revealed that, solid waste collectors (who use handcarts) find it is difficult to collect solid waste in areas where accessibility is constrained and even foot paths are narrow. Many residents living in inaccessible areas found themselves hardly accessed by the solid waste collectors. This was revealed by $42 \%$ of the respondent. Therefore, they have used that loophole to justify throwing solid waste haphazardly into river streams and the environment.

\subsubsection{Institutional Challenges: Lack of Cooperation among the Existing Solid Waste Management Organs}

In an interview with chairmen of community organizations (4 of them) who have been involved with solid waste collection, it was reported that, lack of cooperation among the existing organs is a major hindrance to effective solid waste management. The upshot is that, without cooperation solid waste management will continue to be ineffective. An increasing establishment of any new community organization to deal with solid waste management is not a solution to solid waste problems in the settlement. Fortunately, chairman of the old and existing community organizations for solid waste management have realised that. This perception indicates existence of cooperation issues in solid waste management, among others.

\subsubsection{Financial Challenges: Constraints on Cost Recovery Levels}

Having effective and efficient SWM services requires sustainable financial resources. The study has revealed that, financial stability of KEMAMUSA (the organ which was until recently dealing with solid waste collection) 


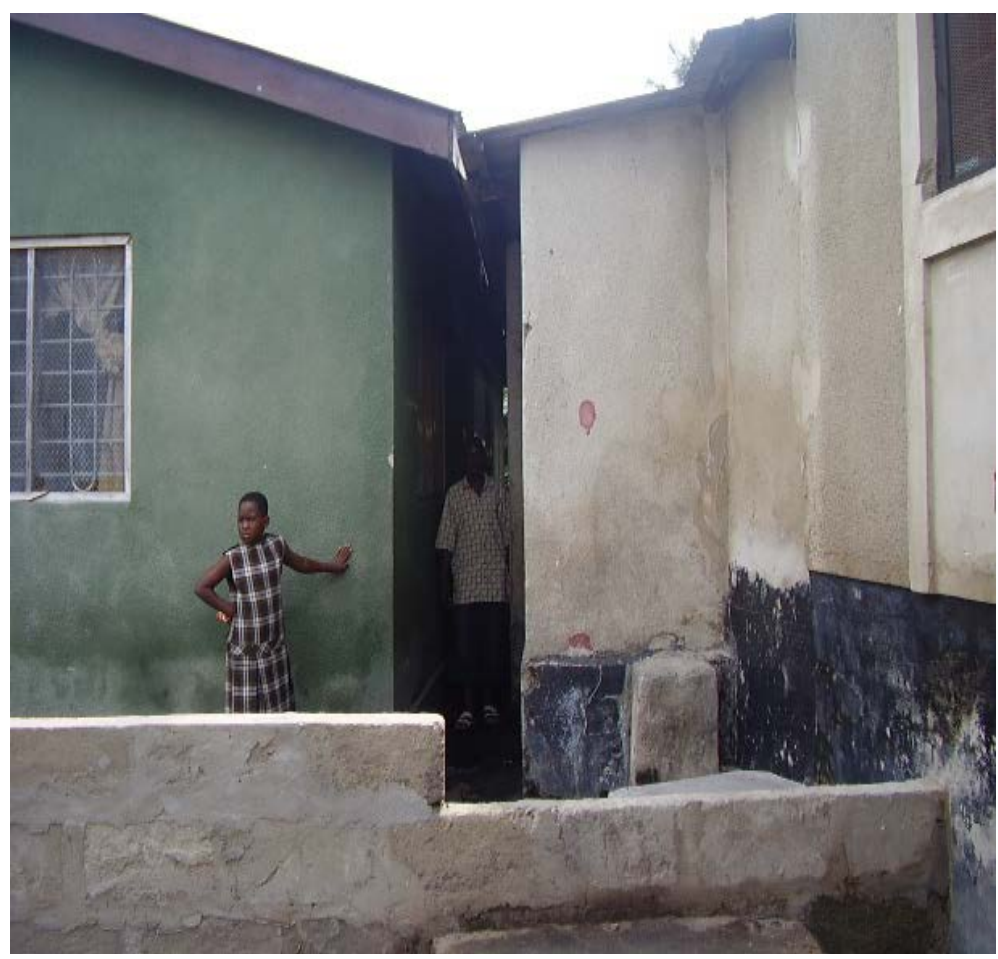

Figure 6. Houses built without setbacks tend to constrain access for solid waste collection.

is not sustainable. The chairman of KEMAMUSA reported that, despite the reduction of solid waste collection fees from 3000 to Tshs 1000 per collection, public cooperation is still very low. It was revealed further that, it is not that local community members cannot afford paying the Tshs 1000 fee. The problem is priority setting and lack of willingness to pay for the solid waste collection fee. This finding is inline with literature [6] [13].

\subsubsection{Perceptional Challenge: Unwillingness of Local Community to Participate in Collection and Pay for Solid Waste Collection Fees}

For successful solid waste management, a positive perception of a service being rendered and willingness of the service users are important parameters to consider. The study has revealed that, household contribution to solid waste collection fee is very weak. This indicates a negative perception and lack of willingness to pay for the service being rendered. The finding that service users are unwilling to pay for the service is similar in other areas as reported by Sujauddin et al. (2008) [6]. In Keko Machungwa, survey results show that $63 \%$ of the respondents have the perception that solid waste collection is the responsibility of the Government. In addition, the study revealed that local community is more willing to pay for other public services like electricity and water unlike solid waste collection.

\section{Conclusion}

This study examined challenges facing solid waste management initiatives in Keko Machungwa informal settlement. Survey results indicate that, at a waste generation rate of $0.95 \mathrm{~kg} / \mathrm{cap} /$ day Keko Machungwa produces 16 tones of solid wastes per day, based on a population of 16648 . Among 16 tones of solid wastes, about 4.56 tones (28.5\%) are collected. This finding shows that, large amount (71.5\%) of solid waste remain uncollected and thus causing threat to the environment. The study revealed that solid waste management in Keko Machungwa is constrained by financial constraints resulted from unwillingness of the service users, lack of cooperation among the existing solid waste management organs, inaccessibility to some parts of the settlement and low public participation and cooperation. Therefore, for improving solid waste management in future, the following measures are suggested. 


\subsection{Alliance among the Existing Organs}

The study finds that, among the four groups established for solid waste collection, only one group continues with solid waste collection in Keko Machungwa. One of the reasons to that is lack of cooperation. Therefore, for efficiency of solid waste collection, alliance among the existing organ dealing with solid waste collection is very crucial.

\subsection{Placing Dust-Bins in Different Points within the Settlement}

Inaccessibility of some areas of Keko Machungwa prevents solid waste collectors who use handcarts to collects solid wastes in every part of the settlement. For improving solid waste collection in such places, there is a need for placing dust-bins in different points within the settlement. The points should be easily accessible by both solid waste collectors and local community. Waste from inaccessible locations should be collected in residential improvised bins including plastic bags. Then, these should be carried on shoulders and heads by individual waste pickers to locations where waste bins reachable by cart pullers and pushers are stationed.

\subsection{Linking Solid Waste Collection Fees to Other Public Services Provided}

About 1000 households were found to be paying a waste collection fee. The rest (3208) are unwilling to pay the collection fee thus they use improper ways of solid waste disposal. On a positive side, this study has revealed that almost all the 4208 households in Keko Machungwa pay for other services including water, electricity, telecommunication, and mobile phones. This presents an opportunity to improve solid waste management and related revenue collections in Keko Machungwa. That is, solid waste collection fees need to be linked and integrated into payment systems of the other services that people are willing to pay for like mobile phone, electricity and water supply.

\subsection{Education and Awareness Creation Campaigns Accompanied with Community Consultation}

Unwillingness of the local community to pay for the service reduces income and has negative consequences for the motivation of the solid waste collectors. Education and awareness creation campaigns accompanied by community consultation can help to enhance willingness of the local community. This way, solid waste management, and particularly collection would improve tremendously.

\section{Acknowledgements}

The author wishes to thank all those whose support had a contribution in the production of this paper. Included in the list of valuable support are local leaders, residents, and representatives of groups involved in solid waste management. Equally important is the financial support from Conreeb Company LTD which was instrumental in accomplishing this research.

\section{References}

[1] Cleland, J. (1996) Demographic Data Collection in Less Developed Countries 1946-1996. Population Studies, 50, 433-450. http://dx.doi.org/10.1080/0032472031000149556

[2] Maleka, M.R.L. (2004) The Consequences of High Population Growth in Developing Countries: A Case Study of South Africa. PhD Dissertation, Department of Economics, Vista University, Pretoria.

[3] DFID (2007) Moving out of Poverty-Making Migration Work Better for Poor People. Department for International Development. http://www.migrationdrc.org/publications/other publications/Moving Out of Poverty.pdf

[4] Minghua, Z., Xiumin, F., Rovetta, A., Qichang, H., Vicentini, F., Bingkai, L., Giusti, A. and Yi, L. (2009) Municipal Solid Waste Management in Pudong New Area, China. Journal of Waste Management, 29, 1227-1233. http://dx.doi.org/10.1016/j.wasman.2008.07.016

[5] Burntley, S.J. (2007) A Review of Municipal Solid Waste Composition in the United Kingdom. Journal of Waste Management, 27, 1274-1285. http://dx.doi.org/10.1016/j.wasman.2006.06.018

[6] Sujauddin, M., Huda, M.S. and Rafiqul Hoque, A.T.M. (2008) Household Solid Waste Characteristics and Management in Chittagong, Bangladesh. Journal of Waste Management, 28, 1688-1695. 
http://dx.doi.org/10.1016/j.wasman.2007.06.013

[7] Guerrero, L.A., Maas, G. and Hogland, W. (2013) Solid Waste Management Challenges for Cities in Developing Countries. Waste Management, 33, 220-232. http://dx.doi.org/10.1016/j.wasman.2012.09.008

[8] Sharholy, M., Ahmad, K., Vaishya, R.C. and Gupta, R.D. (2007) Municipal Solid Waste Characteristics and Management in Allahabad, India. Journal of Waste Management, 27, 490-496. http://dx.doi.org/10.1016/j.wasman.2006.03.001

[9] Ivy, N., Uddin, M.M. and Hossain, M. K. (2013) People’s Perception on Using Waste Bins in Reduce, Reuse and Recycle (3Rs) Process for Solid Waste Management (SWM) in Chittagong, Bangladesh. International Journal of Applied Science, Technology and Engineering Research, 2, 30-40.

[10] Lohri, C.R., Camenzind, E. J. and Zurbrügg, C. (2013) Financial Sustainability in Municipal Solid Waste Management - Costs and Revenues in Bahir Dar, Ethiopia. Waste Management, 34, 542-552. http://dx.doi.org/10.1016/j.wasman.2013.10.014

[11] United Republic of Tanzania (URT) (2004) City Profile for Dar es Salaam. Government Printers, Dar e Salaam.

[12] Hazra, T. and Goel, S. (2009) Solid Waste Management in Kolkata, India: Practices and Challenges. Waste Management, 29, 470-478. http://dx.doi.org/10.1016/j.wasman.2008.01.023

[13] Onyanta, A. (2012) Privatising Services as if People Matter: Solid Waste Management in Abuja, Nigeria. Policy Notes, the Nordic African Institute. http://nai.diva-portal.org/smash/get/diva2:539315/FULLTEXT01.pdf

[14] Henry, R.K., Zhao, Y.S. and Dong, J. (2006) Municipal Solid Waste Management Challenges in Developing CountriesKenyan Case Study. Waste Management, 26, 92-100. http://dx.doi.org/10.1016/j.wasman.2005.03.007

[15] Liyala, C.M. (2011) Modernising Solid Waste Management at Municipal Level: Institutional Arrangements in Urban Centres of East Africa. Ph.D. Thesis, Environmental Policy Series, Wageningen University, Wageningen.

[16] Akateba, M.A. and Yakubu, I. (2013) Householder’s Satisfaction towards Solid Waste Collection Services of Zoomlion Ghana Limited in Wa, Ghana. European Scientific Journal, 9, 198-213.

[17] Bubegwa, S. (2012) An Overview of Solid Waste Management in the City of Dar es Salaam. The Coast East Africa Solid Waste Management and Gas to Energy Best Practices Workshop, Sugar Beach Hotel, Flic en Flac, Mauritius, 10-13 September 2012. https://www.globalmethane.org/documents/events_land_120910_12.pdf

[18] United Republic of Tanzania (2013) Population and Housing Census, Population Distribution by Administrative Areas. National Bureau of Statistics, Ministry of Finance Dar es Salaam and Office of Chief Government Statistician President’s Office, Finance, Economy and Development Planning Zanzibar, Government Printers, Dar es Salaam.

[19] Kaseva, M.E. and Mbuligwe, S.E. (2005) Appraisal of Solid Waste Collection Following Private Sector Involvement in Dar es Salaam. Habitat International, 29, 353-366. http://dx.doi.org/10.1016/j.habitatint.2003.12.003

[20] Halla, F. and Majani, B. (1999) Innovative Ways for Solid Waste Management in Dar es Salaam: Towards Stakeholder Partnerships. Habitat International, 23, 351-361. http://dx.doi.org/10.1016/S0197-3975(98)00057-5

[21] Kasala, E.S. (2013) Operationalizing Strategic Urban Development Planning: The Case of Dar es Salaam City, Tanzania. Ph.D. Dissertation, University of Dar es Salaam, Dar es Salaam.

[22] Baradyana, J.S. and Ame, A. (2005) Quantitative Techniques for Business Decisions. Mkuki na Nyota, Dar es Salaam.

[23] Sakijege, T., Sartohadi, J., Marfai, M.A., Kassenga, G. and Kasala, S. (2014) Government and Community Involvement in Environmental Protection and Flood Risk Management: Lessons from Keko Machungwa, Dar es Salaam, Tanzania. Journal of Environmental Protection, 5, 760-771. http://dx.doi.org/10.4236/jep.2014.59078 
Scientific Research Publishing (SCIRP) is one of the largest Open Access journal publishers. It is currently publishing more than 200 open access, online, peer-reviewed journals covering a wide range of academic disciplines. SCIRP serves the worldwide academic communities and contributes to the progress and application of science with its publication.

Other selected journals from SCIRP are listed as below. Submit your manuscript to us via either submit@scirp.org or Online Submission Portal.
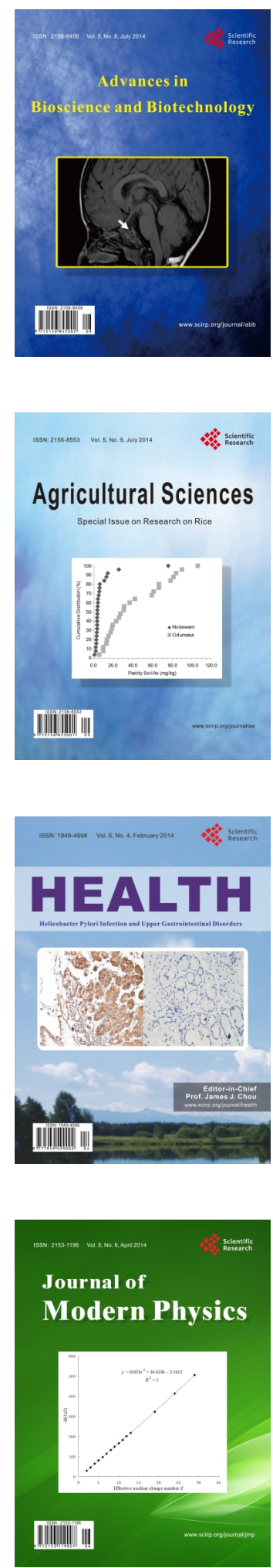
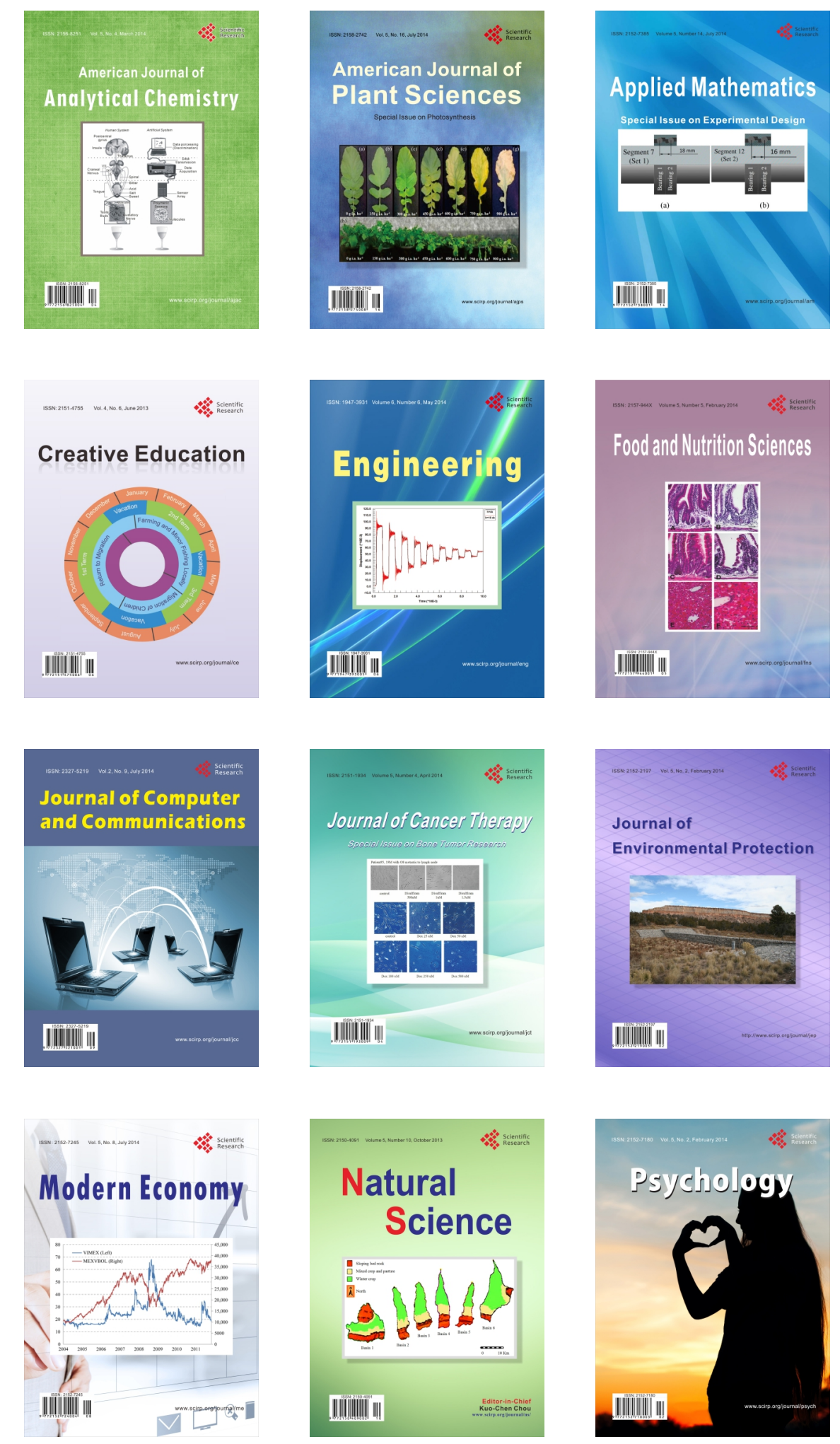